\title{
Microfinance as a Mechanism against Financial Exclusion in the European Rural Areas - an Inspiration for the Czech Republic
}

\author{
Gabriela Chmelíková ${ }^{1}$, Annette Krauss², Francois Lategan ${ }^{3}$ \\ ${ }^{1}$ Mendel University in Brno, Czech Republic \\ ${ }^{2}$ University of Zurich, Switzerland \\ ${ }^{3}$ Research Associate, Nelson Mandela University, Republic of South Africa
}

\begin{abstract}
One of the factors influencing the emergence of disparities between rural and urban regions is the varying level of financial inclusion of the population. The system of microfinancing is becoming an important mechanism against poverty and social exclusion in Europe. However, there is available very limited legal, regulatory and historical information on the microfinance system in the Czech Republic. As a result, microfinance institutions are absent and small entrepreneurs tend to use expensive consumer credit products, thereby increasing the risk of over-indebtedness. The aim of this research is to examine the repayment performance of the European microfinance institutions with increased share of clients from rural areas. Based on an empirical statistical analysis of an unique European microfinance institutions' database, we are presenting evidence that suggests that microfinance systems perform better in rural than in urban areas. This finding is strongly recommended for consideration in the development of policies to guide legal frameworks regarding microfinancing.
\end{abstract}

\section{Keywords}

Microfinancing industry, quality of portfolio, rural economic development, social capital.

Chmelíková, G., Krauss, A. and Lategan, F. (2021) "Microfinance as a Mechanism against Financial Exclusion in the European Rural Areas - an Inspiration for the Czech Republic", AGRIS on-line Papers in Economics and Informatics, Vol. 13, No. 4, pp. 61-69. ISSN 1804-1930. DOI 10.7160/aol.2021.130406.

\section{Introduction}

There is sufficient evidence suggesting a wide variety of inhabitants being either excluded from the job market or with a low probability of gaining access to a sustainable job. These excluded groups, in particular, include mothers on and directly after maternity leave, elderly people, unemployed graduates and ethnic minorities. These groups often also include persons who want to start or further develop their own businesses (microenterprises, self-employment) but due to social exclusion pressures they experience difficulties with obtaining credit facilities to do so. The exclusion of socially marginalized people from traditional banking services constitutes an important obstacle to the establishment of new business activities. The European Anti-Poverty Network, the EAPN, defines "social exclusion" as the social, financial, political and other similar processes which push individuals and groups of people to the edge of society eventually limiting their access to resources and opportunities. (EAPN, 2016)
The risk of social exclusion and poverty is higher in the rural regions in comparison to urban ones. Kučerová (2018) states that European rural areas are characterized by a higher degree of income poverty compared to urban areas across all European Union (EU) members. The Czech Republic is not an exception (Alina et al., 2020). This finding is supported by results of an empirical study carried out by Střeleček and Zdeněk (2011) who reported significant differences of incomes between rural and non-rural households in the Czech Republic. Stejskal and Stávková (2010) supported the divergences between rural and urban areas in their study on the incomes of Czech farmers. They reported that $12.1 \%$ of farming households are being threatened by income poverty. This statement is confirmed by the findings of Střeleček et al. (2004), who concludes that important differences in Czech regional structure are decisive in their influence on the development of rural populations.

According to Lee and Luce (2018) there is mounting evidence in the developed world to suggest that there 
is geographical variation in access to finance. Zhao and Jones-Evans (2016) found evidence suggesting the presence of a regional-specific influence on small firms' access to bank finance. They presented evidence suggesting that the economic region where entrepreneurs are located matters and the operational proximity between banks and borrowers' communities appear to be important in small and medium enterprises' access to bank finance. Bečicová and Blažek (2015) confirmed that there is a credit gap in the Czech periphery. They concluded in their study, that entrepreneurs from periphery areas face the problem that the value of their premises, when setting them as collateral, is significantly underestimated.

The European Microfinance Network (EMN) states that microfinance offers people in many parts of the world, who are being excluded from formal financial services, the opportunity to obtain microloans in order to generate an income and engage in productive activities, often by expanding their small businesses (Lorenzi, 2016). According to the EMN (2019), microfinance, and microcredit, is not only developed in Africa, Latin America or Asia but also in Europe, where it has been initiated and implemented and has long proven necessary.In the recent past the European microfinance sector has made an important contribution to supporting micro-enterprises to establish self-employment opportunities as well as promoting social inclusion (EMN, 2019). While there is clear evidence that the microfinance industry in Europe is an effective financing channel for stimulating job creation and promoting social inclusion, the microfinance market in the Czech Republic is still in its infancy (Chmelíková et al.,2019). According to the Czech Ministry of Labour and Social Affairs, there is a lack of legal and regulatory support and no clear definition of the microfinance system. As a result, effective microfinance institutions (MFI) are absent, thus severely limiting the access of socially excluded people to financial credit resources. EMN (2019) did not identify any MFI in the Czech Republic. As a consequence, microfinance entrepreneurs tend to use very expensive conventional consumer credit products (from both bank and non-bank institutions) without any counselling services and increasing an already high risk of over-indebtedness. The inspiration for designing and launching microfinance legislation should be found in other European countries which have successfully developed microfinance systems. However, little is known about the impact of existing European microfinance on both social and financial performance of microfinance institutions.

Compared to traditional microfinance institutions from developing countries, the European ones in general suffer also from the lack of soft information about borrowers, collective wisdom, and the effectiveness of peer pressure in the relationship between lenders and borrowers. This information asymmetry leads to higher rates of interest or increased demands on the collateral value of property or fixed assets offered. The main difference between the two areas originates from the structure of the systems. Whereas microfinance clients and MFIs in developing countries are mostly a part of social networks that create social collateral for them (Biekpe, 2007), microfinance clients in Europe usually stand in an anonymous position. However, the intensity of social ties differs with the character of the regions. Theoretical models (Postelnicu, 2014) and empirical studies from developing economies (e.g. Karlan (2007), Cassar et al. (2007) and Al-Azzam and Mimouni (2012)) show that clients from rural areas rely upon social networks to overcome the information asymmetry better than lenders from urban areas.

In order to succeed with social inclusion and job creation efforts in the rural areas of the Czech Republic, there is a need to set up and develop the microfinance sector and especially to enhance the sustainability of microfinance institutions. As the European microfinance sector has expanded in recent years it can offer inspiration for the Czech Republic when setting up its microfinance system. However, little is known about the European microfinance industry and its drivers of both social and financial performance.

The aim of this research is to examine whether the European microfinance institutions with clients from rural areas perform better than remaining institutions. This expectation of better performance is driven by the fact that rural areas have conditions more conducive for the development of social networks than urban ones (Postelnicu, 2014). The social networking can result in conformity behaviour that may positively affect repayment. The study aims to investigate the conjecture that MFIs with clients from rural areas face lower agency conflicts between lenders and borrowers and have therefore improved repayment performance. This knowledge could be beneficial when designing and launching the microfinance system in the Czech Republic. This expectation 
is also driven by the results of Pospěch et al. (2009: 294) who state "that Czech rural areas are becoming a part of what Castells (2000) has termed the "network society", where the geographical borders are being crossed by the strings of networks, tying together what, until recently, has been disconnected." Hubík (2007) sees the Czech countryside as a space which can quickly get ahead of the urban areas thanks to social and technological networks.

The remaining section of the paper is structured as follows: The second part introduces the microfinance industry in the European and develops the testing of the hypothesis, describes the used data and the methodology. The empirical study in the third part focuses on the relationship between repayment and the affiliation with rural areas. The concluding section discusses the main results and offers recommendations for the microfinance industry in the Czech Republic.

\section{Materials and methods}

The European Commission defines the term "microfinance" as financial loans of less than EUR 25,000 , as well as guarantees for new and existing micro-enterprises (EC, 2018). Although the size of the loan may be far less, the specific financial amount will depend on the specific target group that the microcredit or guarantee is provided for and on the purchasing power for the country where the microfinance is provided.

According to the European Microfinance Network (EMN) the European microfinance sector has been steadily growing over recent years. The average number of microloans increased in the European countries from 30 thousand in 2003 to more than 600 thousand in 2017 which means an increase in the value of disbursed microloans from 210 million EUR in 2003 to more than 2000 million EUR in 2017. In 2017 European microfinance institutions reported almost 1 million total active borrowers.

Although these numbers document the overall trend in the Europe, they do not say anything about the distribution of microfinance services in particular countries. Based on data from the EMN Survey (2018), there is geographical variation in the access to microloans. Figure 1 represents the density and intensity of microfinance industry in particular European countries.

The picture documents unequal distribution
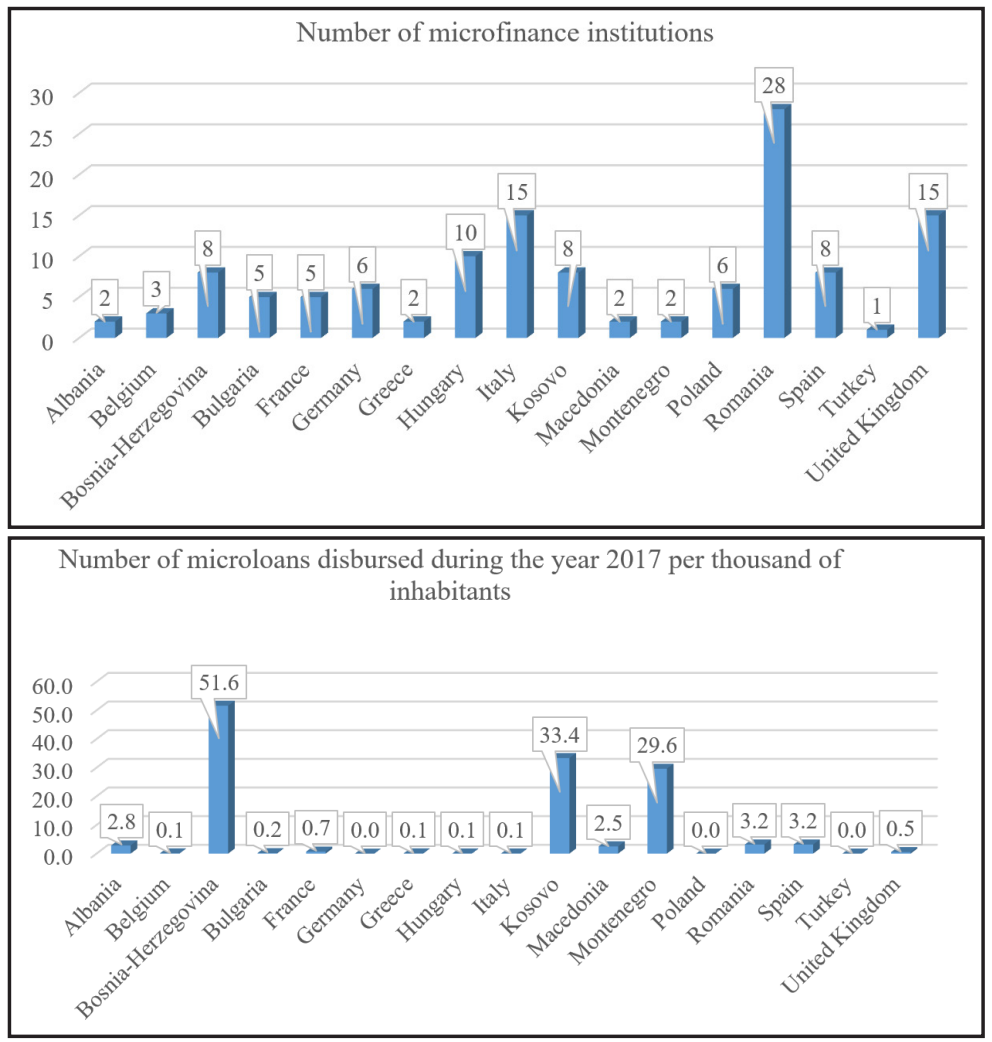

Source: Authors' own elaboration based on EMN (2018) data

Figure 1: Density and intensity of microfinance industry in Europe in 2017. 
of microfinance industry across Europe. The density is represented by number of microfinance institutions in particular countries, the intensity is expressed by number of microloans disbursed during the latest available year 2017 per thousands of inhabitants in particular countries. There are European countries in which microfinance markets are developed not at all or only to a very limited extent. The Czech Republic is, however, one of those countries, where microfinance industry is still in its infancy. The inspiration for designing and launching the microfinance legislative should be found in other European countries which have successfully-developed microfinance systems. However, little is known about the impact of existing European microfinance. A major obstacle in launching and developing microfinance industry in the Czech Republic is missing legislative and regulatory framework. On the other hand, there is a wide range of potential resources for microcredits. Resources for microfinance loans in the Czech Republic can be divided into two basic groups: public and private.

Public sources are largely provided from the EU budget and partly from the national or regional budgets of the Czech Republic. However, the main European microfinance facility for employment and social inclusion in the Czech Republic is still not used.). Public resources are distributed among final users in the following ways:

- Subsidies (irreversible contributions)

- Financial instruments (loans and guarantees)

- Indirect funding support (tax relief, counselling, information services, infrastructure).

Problems arising from the utilization of public sources in the microfinance sector are mostly connected with the fact that microloans or guarantees are often over dimensioned for the needs of micro-enterprises. Furthermore, public resources tend to be limited to certain sectors defined in the individual programs, which excludes potential borrowers. To complicate matters further the support from European public resources is not always stable. Changes in the conditions, aims and forms of micro-aid occur regularly.

Private sources for financing micro-enterprises can be divided into three groups - banking and nonbanking institutions and new forms of financing. Banking and non-banking institutions are regulated by the central body of the Czech National Bank. The conditions for granting credit from banking institutions are considerably stricter than for non-bank institutions, which are however mainly focused on providing consumer credit. New forms of financing, including Crowdfunding or Peer-to-peer financing, represent marginal and limited forms of financing on the Czech financial market.

Problems connected with the microfinancing from private sources are connected particularly with the value of the loans, as the processes in banks are not designed for small loans and also require suitable collateral or proof of income from employment.

\section{Hypothesis}

The theoretical model of Postelnicu (2014), which provided the framework for evaluating the impact of social collateral pledged by group borrowers on group lending repayment, forms the basis for the formulation of our hypothesis. This theoretical model approach stresses the impact of network configuration on the amount of social collateral pledged and shows "why the group lending methodology works better in rural areas than in urban areas, namely because rural social networks are typically denser than urban ones, which results in higher social collateral" (Postelnicu, p.1, 2014). The available evidence on the importance of social ties in microfinance is scarce and stems solely from the conditions of the developing world. However, it confirms the theoretical prediction that social ties among stakeholders significantly influence the repayment performance and decrease the risk associated with the loan agreement. According to Mersland and Strom (2014), several proxies have been used in empirical studies to gauge the intensity of social ties. They include factors such as the duration of the relationship, geographic proximity, character of the relationship, the frequency of contact and sharing between group members. A brief review of the literature conducted by Mersland and Strom (2014) confirmed the unambiguous supreme role of geographic proximity. The social networks may convey soft information about borrower's risk and therefore has the potential to compensate for the lack of hard information. This consequently reduces the need or demand for collateral or high interest rates, which are believed to be major obstacles for sustainable and non-interfering microfinance systems.

The research question can then be formulated to state: "To what extent will the intensity of social 
ties among rural clients of European microfinance institutions improve the quality of a portfolio in terms of the number and value of microloans overdue more than 30 days and/or written-off loans?". Based on the findings from developing countries (e.g., Karlan (2007), Cassar et al. (2007) and Al-Azzam and Mimouni (2012)) and on the theoretical model of Postelnicu (2014), one may assume that the higher the ratio of rural clients in the portfolio of a microfinance institution, the more conducive are circumstances for building social networks, share information among stakeholders, substitute physical collateral and improve the general quality of the portfolio as measured by the number and value of loans written-off. To verify this conjecture, the following hypothesis may be formulated:

H1: The share of rural clients of MFIs is positively related to the quality of portfolio.

In order to test and then possibly support the hypotheses, the following wording has been used for its preliminary version:

H0: The share of rural clients of MFIs is not positively related to the quality of portfolio.

Hypothesis H1 reflects the findings of Al-Azzam and Mimouni (2012) who postulated that geographic proximity improves the repayment performance of borrowers. They confirm the theoretical prediction that internal ties among stakeholders affect their screening, monitoring and enforcement efforts, which in turn determine their repayment performance and the quality of the portfolio. It also reflects the findings of Chmelíková et al. (2019) whose analysis of data from European MFIs confirmed that the share of overdue loans is negatively related to the share of clients from rural areas.

\section{Data}

Data for our analysis come from a comprehensive overview of microcredit suppliers in Europe carried out by European Microfinance Network (EMN). According to EMN (2018), the survey has increased its coverage from 32 microlenders across 10 European countries participating in 2004 to 156 institutions from across 28 countries participating in the most recent survey of 2017. The EMN survey data include the standard MFI yearly indicators in the terms of size, age, legal form, the structure of clients and services, financial ratios, social outreach ratios and portfolio quality of the institutions. For our analysis, we deploy data on the share of rural clients and on quality of outstanding balance portfolio (measured by Write-off ratio and Portfolio overdue more than 30 days ratio) from 447 microfinance suppliers from across 29 European countries each MFI with 2-10 years of data over the period 2008-2017.

\section{Methods}

The financial and portfolio data of individual microfinance institutions are obtained from EMN survey, which covers a panel of 447 microfinance suppliers in the period between 2008 and 2017. The analysis of panel data represents the possibility of a cross-section of the monitored units in the monitored period therefore we deploy the panel regression analysis. A suitable method for processing a large sample is the selected method of panel analysis that allows the inclusion of these amounts of data depending on selected variables. All estimates are made in the software Gretl. We estimated the model with random effects (based on the results of the Hausman test) with robust standard errors, which are consistent against the consequences of autocorrelation and heteroscedasticity. Stationarity of variables was proved with the use of the unit root test Levin, Lin \& Chu for the panel data (Levin et al., 2002).

To test the influence of share of rural clients on the quality of portfolio of European MFIs we use two regression models with the following variables:

\section{- Dependent variables:}

- Portfolio overdue more than 30 days (PAR30), calculated as follows: (Outstanding balance portfolio overdue > 30 days / Gross Loan Portfolio) x 100

- Written off ratio $(W O F)$, calculated as follows: (Value of loans written-off / Average Gross Loan Portfolio) x 100

- Independent variable: Share of rural clients $(R U R)$. This variable describes the share of rural population among all clients of particular microfinance suppliers,

All variables, including a description of the measures used and their descriptive statistics, are summarized in Table 1. 


\begin{tabular}{|c|c|c|c|c|c|c|c|c|}
\hline Variable & Abb. & Description & Mean & Median & Max. & Min. & Std. Dev. & Obs. \\
\hline $\begin{array}{l}\text { Portfolio overdue } \\
\text { more than } 30 \text { days }\end{array}$ & PAR30 & $\begin{array}{l}\text { Outstanding balance } \\
\text { portfolio overdue }>30 \\
\text { days as \% of Average } \\
\text { Gross Loan Portfolio }\end{array}$ & 8.599 & 4.0 & 96.0 & 0.1 & 13.283 & 554 \\
\hline Write-off ratio & WOF & $\begin{array}{l}\text { Value of loans written- } \\
\text { off as \% of Average } \\
\text { Gross Loan Portfolio }\end{array}$ & 3.746 & 2.2 & 24.0 & 0.1 & 4.333 & 364 \\
\hline $\begin{array}{l}\text { Proportion } \\
\text { of clients } \\
\text { from rural areas }\end{array}$ & RUR & $\begin{array}{l}\text { Rural population as } \\
\% \text { of total borrowers }\end{array}$ & 31.354 & 25.00 & 99.3 & 1.0 & 27.475 & 639 \\
\hline
\end{tabular}

Source: Gretl; authors' elaboration

Table 1: Description of variables and summary statistics.

\section{Results and discussion}

The hypothesis $\mathrm{H} 0$ has been tested in order to determine the relationship between the repayment performance of microfinance institutions and their share of clients from rural areas. Table 2 shows the results based on the estimation of the impact of the rural character of clients on the quality of portfolio of European MFIs which is expressed by their PAR30 and Write-off ratios.

\begin{tabular}{|c|c|c|}
\hline & $\begin{array}{c}\text { Dependent } \\
\text { Variable }\end{array}$ & $\begin{array}{c}\text { Dependent } \\
\text { Variable }\end{array}$ \\
\hline $\begin{array}{l}\text { Independent } \\
\text { Variable }\end{array}$ & PAR30 & $W$-OFF \\
\hline RUR & $\begin{array}{c}-\mathbf{0 . 0 9 2 4} * * * \\
(0.0000)\end{array}$ & $\begin{array}{c}-\mathbf{0 . 0 2 0 5} * * * \\
(0.0024)\end{array}$ \\
\hline CONSTANT & $\begin{array}{c}\mathbf{1 0 . 5 3 2 7}^{* * *} \\
(0.0000)\end{array}$ & $\begin{array}{c}\mathbf{3 . 7 1 7 8}^{* * *} \\
(0.0000)\end{array}$ \\
\hline AIC & 3456.325 & 1287.996 \\
\hline Observations & 454 & 260 \\
\hline
\end{tabular}

Note: $* * *$ statistical significance at $0,01 \%$ level. Standard Errors are in parenthesis.

Source: Gretl; authors elaboration

Table 2: Model Table.

The negative sign of coefficients $b$ shows, at statistical significant level of $0.05 \%$, that repayment performance of particular MFIs is positively influenced by the higher share of the rural population (the higher are the PAR30 and Write-off ratios the worse is the quality of portfolio and overall repayment performance of the MFIs). This is in line with expectations stemming from previous empirical evidence (Al-Azzam and Mimouni (2012) and Chmelíková et al. (2019) as well as from the theoretical model developed by Postelnicu (2014). The null hypothesis of the independence assumption is rejected based on given statistical significance ( $p$-value is less than the given significance level $\alpha=0.05$ ). We can hence support the base hypothesis that increased share of rural population leads to improved quality of portfolio.

We have built our hypothesis on the theoretical model of Postelnicu (2014), who described denser social networks in rural areas in the comparison to urban ones. These are connected with an increased ability to create social capital and use it as a "soft" collateral in debt-creditor relationships. This connection was empirically verified by Mersland and Strom (2014), Karlan (2007), Cassar et al. (2007), or Al-Azzam and Mimouni (2012), who confirmed similar conclusions to ours in the conditions of developing world.

An important mechanism through which social capital influences the repayment behaviour of microfinance institutions' clients is peer pressure. According to Kandel and Lazear (1992) there is an emotional component of peer pressure that makes it effective in the battle against moral hazard - shame and guilt. Failure to repay a loan may cause a borrower to feel shame if others can observe the failure. The denser ties among borrowers are, the stronger is the influence of peer pressure. The social conditioning of shame can result in conformity behaviour that may positively influence repayment behaviour. Gallenstein et al. (2020) found that borrowers with more close relationships (family and friends) in their borrowing group increase risk-taking yet borrowers with more relationships that induce negative moral emotions (shame and guilt) reduce risk-taking.

Our results demonstrate that social capital helps to convey emotional concepts of shame and guilt and thus helps to improve the repayment performance of those European microfinance institutions, which have higher share of clients 
from rural areas. Our results suggest that the risk of bad loans can be mitigated by peer pressure which consequently decreases the demand for collateral or high interest rates. The lack or undervaluing of physical collateral is seen as the main obstacle in using the bank loans in the peripheral regions of the Czech Republic. Blažek and Bečicová (2015) found that entrepreneurs from Czech periphery face the problem that the value of their premises, when setting them as collateral, is significantly underestimated.

The banking sector in the Czech Republic is strongly centralized (Blažek and Bečicová, 2015), which leads to credit-rationing for businesses located in peripheral regions (Dow, 1992). Blažek and Bečicová (2015) state that in centralized financial systems, the financial resources might be allocated mainly to enterprises located close to the centre, whereas credit applicants situated in distant regions might be exposed to a credit gap or even excluded. The citizens from rural areas thus have less access to capital sources and are being held back in their investment plans by a shortage of finance. Decreased interest of profit oriented banking institutions in rural areas leads thus to lower financial inclusion of rural Czech populations. Microfinance proves therefore to be very effective in the battle against social exclusion. No financial institution has, however, been identified by the authors of the microfinance sector survey in the Czech Republic (EMN, 2019).

\section{Conclusion}

The lack of microfinance institutions in the Czech Republic is certainly a major consequence of the limited legislative framework and regulation developed for this type of financial industry. This has become an object of criticism from the regulatory bodies of the European Union (EMN, 2009). The missing legislatory framework for the microfinance industry is also accompanied by a serious lack of regulatory mechanisms. However, the role of the regulation in this sector is not explicit. Hartarska and Nadolnyak (2007) postulate that regulation has no impact on financial performance and offers weak evidence that regulated MFIs serve less poor borrowers. Mersland and Strøm (2014) show that the launching of regulation into the microfinance sector does not improve social efficiency nor accelerates future development. Their findings are supported by Cull et al. (2009).

Our findings confirm that clients from rural areas have better payment morals, thus improving the performance of the microfinance institutions. This finding is strongly recommended for consideration in the development of policies to guide legal frameworks regarding microfinancing. This may also support the further growth of the microfinancing industry and contribute positively to moderate the regional disparities between rural and urban regions.

To support the genesis of new microfinance institutions in the Czech Republic the policymakers are encouraged to design a suitable legislative framework for this industry. The results of this study clearly suggest that the repayment performance of microfinance institutions in rural areas is higher than in non-rural areas. This finding is consistent with empirical results from the developing world (e.g., Wydick, 1999; Ahlin and Townsend, 2007) and therefore provides a clue to policymakers of how to use the potential of rural networks to improve the repayment behaviour of microfinance clients and their communities. Stiglitz (1990), a former Nobel prize winner, postulates that peer monitoring is largely responsible for the successful financial performance of the microfinance institutions and of similar group lending programs. His analysis suggests some of the ingredients in the design of successful peer monitoring systems - the members of the group must be provided with incentives to monitor the actions of their peers, the smaller the groups are the lower is the risk of free riders' occurrence and the more homogenous the group is the lower is the riskiness of default. Despite Stiglitz's results were driven from conditions in the developing world, the data of our analysis suggest, that similar principles could work in the European countries as well.

\section{Acknowledgements}

We thank Mendel University for partial financial support via an internal grant (IGA) No. FRRMS - IGA - 2020/010.

\section{Corresponding authors}

doc. Ing. Gabriela Chmeliková, Ph.D.

Department of Regional and Business Economics, Faculty of Regional Development and International Studies Mendel University in Brno, Zemédělská 1, 61300 Brno, Czech Republic

Phone: +420731624694,E-mail: gabriela.chmelikova@mendelu.cz 


\section{References}

[1] Ahlin, C. and Townsend, R. M. (2007) "Using repayment data to test across models of joint liability lending”, The Economic Journal, Vol. 117, No. 517, pp. F11-F51. ISSN1468-0297. DOI 10.1111/j.1468-0297.2007.02014.x.

[2] Al-Azzam, M. and Mimouni, K. (2012) "What types of social ties improve repayment in group lending", International Research Journal of Finance and Economics, Vol. 87, pp. 25-32. ISSN 1450-2887.

[3] Alina, J., McGrath, R., Faltová Leitmanová, I. and Petrách, F. (2020) “Using Constraints in Freight Volume to Identify Regional Needs for Roadway Infrastructure”, Promet-Traffic \& Transportation, Vol. 32, No. 2, pp. 237-246. ISSN 2623-9299. DOI 10.7307/ptt.v32i2.3183.

[4] Bečicová, I. and Blažek, J. (2015) "Is there a credit-gap in a periphery? The perception of this problem by small entrepreneurs", Journal of Rural Studies, Vol. 42, pp. 11-20. ISSN 0743-0167. DOI 10.1016/j.jrurstud.2015.09.006.

[5] Biekpe, N. (2007) "Maintaining Sustainable Development in Africa through Microfinance", Africa Growth Agenda, Vol. 2007, No. 7, p. 4-7. ISSN 1811-5187.

[6] Cassar, A., Crowley, L. and Wydick, B. (2007) "The effect of social capital on group loan repayment: evidence from field experiments", The Economic Journal, Vol. 117, No. 517, pp. F85-F106. ISSN 1468-0297. DOI 10.1111/j.1468-0297.2007.02016.x.

[7] Chmelíková, G., Krauss, A. and Dvouletý, O. (2020) "Performance of microfinance institutions in Europe - Does social capital matter?", Socio-Economic Planning Sciences, Vol. 68. ISSN 0038-0121. DOI 10.1016/j.seps.2018.11.007.

[8] Cull, R., Demirgüç-Kunt, A. and Morduch, J. (2009) "Microfinance meets the market", Journal of Economic Perspectives", Vol. 23, No. 1, pp. 167-192. ISSN 1944-7965. DOI 10.1257/jep.23.1.167.

[9] Dow, S. C. (1992) “The regional financial sector: a Scottish case study", Regional studies, Vol. 26, No. 7, pp. 619-631. ISSN 1360-0591. DOI 10.1080/00343409212331347261.

[10] EC (European Comission) (2018) "Finance and Support" [Online]. Available: https://ec.europa. eu/info/business-economy-euro/doing-business-eu/finance-and-support_en [Accessed: 20 August 2020].

[11] EAPN (European Anti-Poverty Network)(2016) "Social Protection". European Anti-Poverty Network [Online]. Available: http://www.eapn.eu/what-we-do/policy-areas-we-focus-on/socialprotection/. [Accessed: 29 April 2020].

[12] EMN (2019) Data collected in the European Microfinance Network's Overview of the Microcredit Sector in the European Union. 2008-2009. 2010-2011, 2012-2013, 2014-2015, 2016-2017.

[13] Hatarska, V. and Nadolnyak, D. (2007) "Do regulated microfinance institutions achieve better sustainability and outreach? Cross-country evidence", Applied Economics, Vol. 39, No. 10, pp. 1207-1222. ISSN 1466-4283. DOI 10.1080/00036840500461840.

[14] Hubík, S. (2007) “Operational zones, countryside, network society”, Agricultural Economics, Vol. 53, No. 11, 491 p. ISSN 0139-570X. DOI 10.17221/977-AGRICECON.

[15] Karlan, D. S. (2007) "Social connections and group banking", The Economic Journal, Vol. 117, No. 517, pp. F52-F84. ISSN 1468-0297. DOI 10.1111/j.1468-0297.2007.02015.x.

[16] Kučerová, E. (2018) "Social inclusion in the context of Czech rural development policy”, Agricultural Economics, Vol. 64, No. 9, pp. 412-422. ISSN 0139-570X. DOI 10.17221/160/2016-AGRICECON.

[17] Lee, N. and Luca, D. (2018) "The big-city bias in access to finance: evidence from firm perceptions in almost 100 countries", Journal of Economic Geography, Vol. 19, No. 1, pp. 199-224. ISSN 1468-2702. DOI 10.1093/jeg/lbx047. 
[18] Levin, A., Lin, C. F. and Chu, C. S. J. (2002) "Unit root tests in panel data: asymptotic and finite-sample properties", Journal of econometrics, Vol. 108, No. 1, pp. 1-24. ISSN 0304-4076. DOI 10.1016/S0304-4076(01)00098-7.

[19] Lorenzi, M. (2016) "Microcredit in the European Union: A Feasible Means for Business Growth and Fair Access to Credit", ECPR $8^{\text {th }}$ Pan-European Conference on the European Union, Trento (Italy), [Online]. Available: https://ecpr.eu/Filestore/PaperProposal/e505c1c4-bb0d-46c0-a55dcbe5043bdbc9.pdf [Accessed: 15 June 2020].

[20] Mersland, R. and Strøm, Ø. (Eds.). (2014) "Microfinance institutions: Financial and social performance", Springer. ISBN 978-1-349-48588-8.

[21] Pospěch, P., Delín, M. and Spěšná, D. (2009) "Quality of life in Czech rural areas", Agricultural Economics, Vol. 55, pp. 284-295. ISSN 0139-570X. DOI 10.17221/1489-AGRICECON.

[22] Postelnicu, L., Hermes, N. and Szafarz, A. (2014) "Defining social collateral in microfinance group lending", In Microfinance Institutions, pp. 187-207. Palgrave Macmillan UK. London. ISBN 978-1-137-39966-3. DOI 10.1057/9781137399663_10.

[23] Stejskal, L. and Stavkova, J. (2010) "Living conditions of Czech farmers according to the EU statistics on income", Agricultural Economics, Vol. 56, pp. 310-316. ISSN 0139-570X. DOI 10.17221/51/2010-AGRICECON.

[24] Stiglitz, J. E. (1990) "Peer monitoring and credit markets", The World Bank Economic Review", Vol. 4, No. 3, pp. 351-366. [Online]. Available: http://documents.worldbank.org/curated/ en/544771468740196425/Peer-monitoring-and-credit-markets [Accessed: 20 June 2020].

[25] Střeleček, F. and Zdeněk, R. (2014) "Incomes of rural and non-rural households in the Czech Republic", Acta Universitatis Agriculturae et Silviculturae Mendelianae Brunensis, Vol. 59, No. 4, pp. 319-326. ISSN 1211-8516. DOI 10.11118/actaun201159040319.

[26] Střeleček, F., Zdeněk, R., Lososová, J. and Jílek, M. (2004) "Social and economic points of the rural development", Agricultural Economics - Czech, Vol. 50, No. 10, pp. 431-444. ISSN 0139-570X. DOI 10.17221/5230-AGRICECON.

[27] Wydick, B. (1999) "Can social cohesion be harnessed to repair market failures? Evidence from group lending in Guatemala", The Economic Journal, Vol. 109, No. 457, pp. 463-475. ISSN 1468-0297. DOI 10.1111/1468-0297.00457.

[28] Zhao, T. and Jones-Evans, D. (2016) "SMEs, banks and the spatial differentiation of access to finance", Journal of Economic Geography, Vol. 17, No. 4, pp. 791-824. ISSN 1468-2702. DOI $10.1093 / \mathrm{jeg} / \mathrm{lbw} 029$. 